D. T. COHEN*, C. ZHANG, C. M. FADZEN, A. J. MIJALIS, L. HIE, K. D. JOHNSON,

Z. SHRIVER, O. PLANTE, S. J. MILLER, S. L. BUCHWALD, B. L. PENTELUTE*

(MASSACHUSETTS INSTITUTE OF TECHNOLOGY, CAMBRIDGE, YALE UNIVERSITY, NEW HAVEN, AND VISTERRA INC., CAMBRIDGE, USA)

A Chemoselective Strategy for Late-Stage Functionalization of Complex Small Molecules with Polypeptides and Proteins Nat. Chem. 2019, 11, 78-85.

\title{
A Chemoselective Conjugation of Peptides with Electron-Rich (Hetero)Arenes
}
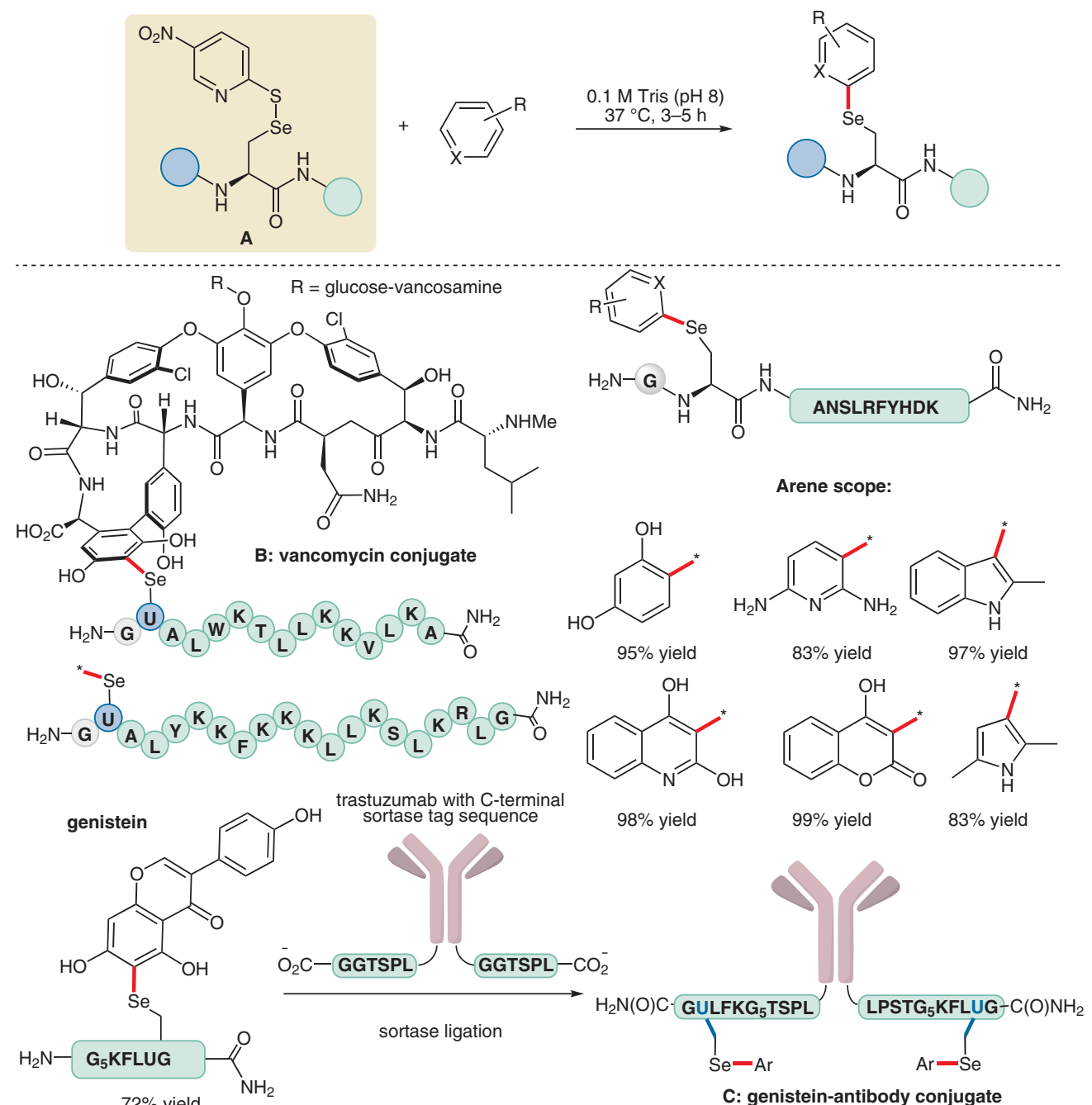

Significance: The site-selective functionalization of peptides with small molecules is a formidable challenge in organic synthesis. Cohen, Pentelute, and co-workers have described a new high-yielding conjugation reaction between electron-rich aromatics and of 2-thiol-5-nitropyridine (TNP)-protected selenocysteine. This methodology is an important advance in the production of homogenously functionalized proteins such as antibody-drug conjugates.

\section{Category}

Chemistry in

Medicine and Biology

Key words

bioconjugation

protein

functionalization

selenocysteine conjugation

bioorthogonal chemistry

late-stage functionalization

natural product functionalization

Comment: A range of unprotected pharmaceutical agents and natural products are competent substrates, as demonstrated by the syntheses of vancomycin-peptide conjugates and a homogenous genistein-trastuzumab conjugate, generated by a two-step selenocysteine ligation-sortagging sequence. In general, electron-rich arenes with acidic $\mathrm{N}-\mathrm{H}$ or $\mathrm{O}-\mathrm{H}$ bonds are the most efficient substrates. $\mathrm{CuSO}_{4}$ and a bipy ligand can be used to promote the reaction with less reactive arenes. 